\title{
Effects of cold-shock triploidy induction treatment on cell cleavage, hatching rate, and survival of triploid larvae of spotted sand bass (Paralabrax maculatofasciatus)
}

\section{Efectos de la triploidía inducida por choque frío sobre la división celular, la tasa de eclosión y la supervivencia larvaria de la cabrilla arenera (Paralabrax maculatofasciatus)}

\author{
Juan Pablo Alcántar-Vázquez ${ }^{1 a}$, Silvie Dumas ${ }^{1 *}$, Renato Peña ${ }^{1}$, Ana M Ibarra ${ }^{2}$ \\ ${ }^{1}$ Centro Interdisciplinario de Ciencias Marinas, Instituto Politécnico Nacional (CICIMAR-IPN), Av. IPN s/n, \\ Col. Playa Palo de Santa Rita, La Paz 23096, Baja California Sur, México. \\ ${ }^{2}$ Centro de Investigaciones Biológicas del Noroeste (CIBNOR), Mar Bermejo 195, Col. Playa Palo de Santa \\ Rita, La Paz 23096, Baja California Sur, México. \\ a Present address: Universidad del Papaloapan (UNPA), Av. Ferrocarril s/n, Col. Ciudad Universitaria, \\ Loma Bonita, Oaxaca 68400, México.
}

* Corresponding author. E-mail: silviedumas@hotmail.com

\begin{abstract}
Three experiments assessed the effects of cold-shock induced triploidy on (1) the incidence of abnormal cell cleavage during embryogenesis, (2) hatching success and the proportion of live yolk-sac larvae in normally cleaved versus abnormally cleaved embryos, and (3) survival of triploid larvae of spotted sand bass (Paralabrax maculatofasciatus). All spawns were obtained by hormonal induction (LHRHa). Triploidy was induced by cold shock shortly after fertilization. In experiment 1 , the percentage of abnormal cell cleavage was significantly higher $(P<0.05)$ in the cold-shocked group than in the control group, while the hatching rate and the proportion of live yolk-sac larvae were significantly lower $(P<0.05)$. In experiment 2 , when normally and abnormally cleaved embryos from the control and cold-shocked groups were incubated separately, normal cleaved embryos in the cold-shocked group showed a significantly higher hatching rate and proportion of live yolk-sac larvae than abnormally cleaved embryos in the same group. No difference was observed in the control group. In experiment 3 , a significant decrease $(P<0.05)$ in the triploidy count was observed throughout the larval period. Final survival was drastically lower for triploid larvae compared to cold-shocked diploids and untreated eggs. Low triploidy percentages at the end of the larval period would seriously hinder the development of triploid sand bass culture.
\end{abstract}

Key words: cell cleavage, embryonic abnormalities, larval mortality, triploidy, Paralabrax maculatofasciatus.

RESUMEN. Se realizaron 3 experimentos para evaluar los efectos de la triploidía inducida por choque frío sobre (1) la incidencia de división celular anormal durante la embriogénesis, (2) la tasa de eclosión y la proporción de larvas vitelinas vivas en los embriones con división celular normal contra los embriones con división anormal y (3) la supervivencia de larvas triploides de la cabrilla arenera (Paralabrax maculatofasciatus). Los desoves se obtuvieron por inducción hormonal (LHRHa). La triploidía se indujo por choque frío poco después de la fecundación. En el experimento 1, el porcentaje de embriones con división anormal fue significativamente más alto $(P<0.05)$ en las larvas tratadas con choque frío que en el grupo control, mientras que la tasa de eclosión y la proporción de larvas vitelinas vivas fueron significativamente más bajas $(P<0.05)$. En el experimento 2, cuando los embriones con divisiones normales y anormales de ambos grupos fueron incubados por separado, los embriones con divisiones celulares normales en el grupo de choque frío presentaron una tasa de eclosión y una proporción de larvas vitelinas vivas significativamente más altas que los embriones con división celular anormal del mismo grupo. No se observaron diferencias en el grupo control. En el experimento 3, se observó una disminución significativa $(P<0.05)$ en la cantidad de triploides a lo largo del periodo larvario. La supervivencia final fue drásticamente menor para las larvas triploides en comparación con las larvas que resultaron diploides después del choque frío o que no recibieron tratamiento. Los bajos porcentajes de triploides al final del periodo larvario limitan el desarrollo del cultivo de la cabrilla arenera triploide.

Palabras clave: división celular, anormalidades embrionarias, mortalidad larvaria, triploidía, Paralabrax maculatofasciatus.

\section{INTRODUCTION}

The spotted sand bass, Paralabrax maculatofasciatus, is a potential species for aquaculture along the northwest coast of Mexico. It is a gynogenetic hermaphrodite. Several aspects of

\section{INTRODUCCIÓN}

La cabrilla arenera, Paralabrax maculatofasciatus, es una especie potencial para la acuicultura a lo largo de la costa noroccidental de México. Es una hermafrodita ginogenética. 
this species's cultivation have been developed in our laboratory, including larval culture (Álvarez-González et al. 2000), juvenile nutrition (Álvarez-González et al. 2001), and growout in sea cages (Grayeb-del Alamo 2001). However, sexual maturation occurs precociously, before commercial size is reached (unpublished data). This is considered a major problem because sexual maturation is accompanied, in many species, by a decrease in survival and growth rate (Felip et al. 2001, Piferrer et al. 2009).

Triploidy induction is the most common type of chromosome manipulation in fish when the goal is to produce sterile fish for aquaculture (Piferrer et al. 2009). Triploidy is achieved by forcing the retention of the second polar body shortly after fertilization, using one of several methods, including thermal shock (cold or heat) and hydrostatic pressure (Dunham 2004). Most studies using chromosome set manipulation in marine species have focused on finding the right combination of treatment variables to induce triploidy, and examining triploid growth during the juvenile and adult stages, hematological dynamics, performance under stress, and gonad development (Piferrer et al. 2000, Felip et al. 2001, Alcántar-Vázquez et al. 2008). However, embryogenesis and survival through the larval period in triploid marine fish have received little attention to date.

Some studies report an increase in the number of dead embryos and low hatching percentages in triploids (Piferrer et al. 2003, Peruzzi et al. 2007); however, none have reported which alterations in the embryonic development are causing mortality. Early embryogenesis consists of a series of mitotic divisions known as cell cleavage. Each division produces new cells called blastomeres. Embryos containing unusual arrangements of blastomeres are considered to exhibit 'abnormal cleavage'. Abnormal cell cleavage early in embryogenesis is detrimental (Avery and Brown 2005). An abnormality in one or more blastomeres may have a greater impact on development than deformity in 1 or 2 cells later in development (Kjørsvik et al. 1990). Positive correlations between the rates of normal early cleavage and the subsequent hatching success have been reported for different species (Kjørsvik et al. 2003, Rideout et al. 2004, Penney et al. 2006). Little is known about the effects of triploidy induction on cellular cleavage and how it affects survival at hatching (Sultana 2005).

Higher mortality in triploids than in diploids is also observed in larval culture (Piferrer et al. 2003, Opstad et al. 2013). Different explanations have been proposed to explain this early mortality in triploids: the timing or magnitude of the treatment, the duration of that treatment (Johnstone 1985, Piferrer et al. 2003), and the newly acquired triploid condition, which involves the presence of a third set of chromosomes (Felip et al. 1997, Piferrer et al. 2000).

A cold shock method for inducing triploidy in the spotted sand bass has been developed in our laboratory (AlcántarVázquez et al. 2008). However, cold shock treatment does not always induce $100 \%$ triploidization. In the aftermath of
En nuestro laboratorio se han abordado varios aspectos relacionados con el cultivo de esta especie, incluyendo el cultivo de larvas (Álvarez-González et al. 2000), la nutrición de juveniles (Álvarez-González et al. 2001) y su engorde en jaulas marinas (Grayeb-del Alamo 2001). No obstante, esta especie llega a la maduración sexual antes de alcanzar la talla comercial (datos no publicados). Esto se considera un grave problema ya que la madurez sexual se relaciona, en muchas especies, con una disminución de la tasa de crecimiento y supervivencia (Felip et al. 2001, Piferrer et al. 2009).

La inducción de la triploidía es la técnica de manipulación cromosómica más usada cuando el objetivo es producir peces estériles para la acuicultura (Piferrer et al. 2009). La triploidía se logra forzando la retención del segundo cuerpo polar poco después de la fecundación, mediante uno de varios métodos, como choque térmico (frío o caliente) y presión hidrostática (Dunham 2004). La mayoría de los estudios de manipulación cromosómica se han enfocado en encontrar la combinación correcta de las variables para inducir la triploidía y en examinar el crecimiento de individuos triploides durante las etapas juvenil y adulta, la dinámica hematológica, el rendimiento en condiciones de estrés y el desarrollo gonádico (Piferrer et al. 2000, Felip et al. 2001, Alcántar-Vázquez et al. 2008). Por otro lado, la embriogénesis y la supervivencia durante el periodo larval de peces marinos triploides han recibido poca atención hasta la fecha.

Algunos estudios han registrado un aumento en el número de embriones muertos y bajos porcentajes de eclosión de larvas triploides (Piferrer et al. 2003, Peruzzi et al. 2007); sin embargo, ninguno ha documentado cuáles son las alteraciones en el desarrollo embrionario que causan la mortalidad. La embriogénesis temprana consiste en una serie de divisiones mitóticas conocida como división celular. Cada división produce nuevas células llamadas blastómeros. Cuando los embriones contienen arreglos inusuales de blastómeros se considera que presentan 'división anormal'. Si la división celular anormal ocurre temprano en la embriogénesis puede ser detrimental (Avery y Brown 2005). Una anomalía en uno o más blastómeros puede tener un mayor impacto en el desarrollo que una deformidad en 1 o 2 células más adelante (Kjørsvik et al. 1990). Se han documentado correlaciones positivas entre las tasas de división normal temprana y el éxito de eclosión para diferentes especies (Kjørsvik et al. 2003, Rideout et al. 2004, Penney et al. 2006). En general, poco se sabe de los efectos de la inducción de la triploidía sobre la división celular y cómo afecta el éxito de eclosión (Sultana 2005).

Durante el cultivo de larvas, también se ha observado una mayor mortalidad de triploides que de diploides (Piferrer et al. 2003, Opstad et al. 2013). Se han propuesto diversas explicaciones para explicar esta mortalidad temprana de larvas triploides, incluyendo el momento o la magnitud del tratamiento, la duración del tratamiento (Johnstone 1985, 
cold shock treatment, the remaining diploid individuals are known as cold-shocked diploids. In a previous experiment of triploidization in spotted sand bass, the ratio of triploids to cold-shocked diploids was 9:1 at hatching; but after 10 months of culture, that ratio had changed to $1: 3$, showing a 27 times higher mortality rate in triploid larvae than in coldshocked diploids (unpublished results). Similar results have not been reported for other species.

The objectives of this study were to look for some alterations in embryogenesis of spotted sand bass that could explain the high mortality of triploids during this period and to know if the low triploidy percentage observed in 10-month juveniles was repeatable and when it happened. Experiment 1 recorded the occurrence of abnormal cleavage in diploid and cold-shocked spotted sand bass embryos. Experiment 2 examined differences in hatching success and early survival between normal and abnormally cleaved embryos. Experiment 3 evaluated triploidy percentages during the larval period in individual spawns (control and cold-shocked groups).

\section{MATERIALS AND METHODS}

\section{Broodstock management, spawning, and triploidy induction}

Wild broodstock (females: 150-300 g; males: 300-500 g) of spotted sand bass were captured in the southern part of the Gulf of California (Bahía de La Paz, Mexico, 24 $4^{\circ}$ N, $110^{\circ} 19^{\prime} \mathrm{W}$ ) during the reproductive season. Upon arrival at the laboratory, fish were anesthetized with 2-phenoxyethanol (400 $\mathrm{mg} \mathrm{L}^{-1}$ ) and assessed for gonadal maturity. Spawning was induced with LHRHa as described in Alcántar-Vázquez et al. (2008). Hydrated oocytes were collected by manual stripping. Approximately $1 \mathrm{~h}$ prior to female cannulation, sperm was collected using a 1-mL syringe and kept on ice at $4^{\circ} \mathrm{C}$. Triploidy was induced as described in AlcántarVázquez et al. (2008). Five minutes after fertilization, the embryos were subjected to $8 \pm 0.3^{\circ} \mathrm{C}$ cold shocks for $20 \mathrm{~min}$.

\section{Experiment 1: Effect of cold shock treatment on early cell cleavage}

Spawns from 13 females were used: 7 in 2008 and 6 in 2009. Each spawn was fertilized with sperm from 3 to 4 males. Fertilized eggs from each female were divided into 2 groups: control (2 replicates) and cold-shocked (3 replicates). After the cold shock treatment, approximately 50 cold-shocked eggs and 50 eggs from the control group were placed in 12-well microplates (4 eggs per well) filled with sterile seawater. Normal or abnormal cleavage was determined under a dissecting optical microscope. Because development occurs rapidly in spotted sand bass, some spawns were observed as early as the 4-cell stage, while others were observed as late as the 32-cell stage, but never
Piferrer et al. 2003) y la recién adquirida condición triploide, que involucra la presencia de un tercer juego de cromosomas (Felip et al. 1997, Piferrer et al. 2000).

En nuestro laboratorio se ha desarrollado un método de choque frío para inducir la triploidía en la cabrilla arenera (Alcántar-Vázquez et al. 2008); sin embargo, el tratamiento de choque frío no siempre induce una triploidización del $100 \%$. A los individuos que resultaron diploides a pesar de haber sido tratados con choque frío se les conoce como larvas diploides sometidas a choque frío. En un experimento previo con la cabrilla arenera, la proporción de triploides con respecto a diploides sometidos a choque frío fue 9:1 a la eclosión, pero después de 10 meses de cultivo, la proporción había cambiado a 1:3, lo que muestra que la tasa de mortalidad de las larvas triploides fue 27 veces mayor que la de las larvas diploides sometidas a choque frío (resultados no publicados). No se han documentado resultados similares para otras especies.

Los objetivos de este estudio fueron tratar de determinar algunas alteraciones en la embriogénesis de la cabrilla arenera que podrían explicar la alta mortalidad de triploides durante este periodo, así como determinar si se repetía el bajo porcentaje de triploidía en los juveniles de 10 meses y cuándo sucedía. Para esto, se realizaron 3 experimentos: en el experimento 1 se registró la ocurrencia de división celular anormal en embriones de la cabrilla arenera sometidos y no sometidos a choque frío, en el experimento 2 se examinaron las diferencias en el éxito de eclosión y la supervivencia temprana entre los embriones con divisiones celulares normales y anormales, y en el experimento 3 se evaluaron los porcentajes de triploidía durante el periodo larvario en desoves individuales (grupo control y grupo sometido a choque frío).

\section{MATERIALES Y MÉTODOS}

\section{Manejo de reproductores, eclosión e inducción de la triploidía}

Se capturaron reproductores silvestres (hembras: 150-300 g; machos: 300-500 g) de la cabrilla arenera en la parte sur del golfo de California (bahía de La Paz, México, $24^{\circ} 9^{\prime} \mathrm{N}, 110^{\circ} 19^{\prime} \mathrm{W}$ ) durante la temporada reproductiva. Al llegar al laboratorio, los peces fueron anestesiados con 2-fenoxietanol $\left(400 \mathrm{mg} \mathrm{L}^{-1}\right)$ y se determinó su madurez gonádica. Se indujo el desove con LHRHa siguiendo el método descrito por Alcántar-Vázquez et al. (2008). Se recolectaron ovocitos hidratados mediante extracción manual. Aproximadamente $1 \mathrm{~h}$ antes de la canulación de hembras, se recolectó semen con una jeringa de $1 \mathrm{~mL}$ y se mantuvo en hielo a $4{ }^{\circ} \mathrm{C}$. Se indujo la triploidía siguiendo a Alcántar-Vázquez et al. (2008). Cinco minutos después de la fecundación, los embriones fueron sometidos a choque frío $\left(8 \pm 0.3{ }^{\circ} \mathrm{C}\right)$ durante $20 \mathrm{~min}$. 
later. Any embryo that was not divided in a normal 'boxed formation' was considered abnormal (Fig. 1a, b). Embryos at the 32-cell stage were considered normal or abnormal based on the structural organization of the blastomeres (Fig. 1c, d). Following this evaluation, the 12-well microplates were placed in a temperature-controlled chamber $\left(25^{\circ} \mathrm{C}\right)$ for incubation. After hatching, the number of dead embryos, and live and dead yolk-sac larvae were recorded. Yolk-sac larvae that were bent and slightly opaque were considered dead (Fig. 1e, f).

\section{Experiment 2: Link between abnormal cleavage and hatching success}

The above procedure was repeated in 2009. This time, in order to determine whether the hatching results were linked to the abnormal cleavage, embryos were separated into 4 groups: (1) normally and (2) abnormally cleaved embryos from the control group, and (3) normally and (4) abnormally cleaved embryos from the cold-shocked group. They were placed separately in 12-well microplates and incubated as described above.

\section{Experiment 3: Effect of triploidy on survival during the larval period}

The triploidy percentage was examined at different moments during the larval period. Hormone-induced spawns of spotted sand bass are very small so it was impossible to use replicates. For this reason, the experiment was performed with 3 individual spawns. Four to 6 males were used to fertilize the eggs from each female. Cold shock was applied as described above. Spawns with triploidy percentages around $80 \%$ were selected to get larvae of both ploidy (triploid and cold-shocked diploid) in order to follow the ploidy percentages during larval culture. Eggs were immediately transferred for incubation at $25^{\circ} \mathrm{C}$ and 35 salinity to 2 aerated $120-\mathrm{L}$ conical tanks with water circulation. Twenty-four hours after hatching, the number of yolk-sac larvae was estimated using volumetric methods. Larval density was set using the number of larvae that had survived the cold shock treatment. Control and cold-shocked larvae were transferred to 2 separate $100-\mathrm{L}$ tanks. A photoperiod of 13:11 (light:dark) was used. Temperature and oxygen were measured daily using an oxymeter ( \pm 0.1 ) (YSI model 58, Yellow Springs Instrument Co., Inc., Ohio). Salinity was measured using a refractometer (Aquafauna, Tokyo).

The feeding schedule during the culture trial was as follows: S-type rotifers (Brachionus plicatilis) enriched with Selco (Artemia System, Ghent, Belgium) were offered from 1 to 18 days after hatching (DAH) at a density of 4-15 rotifers per milliliter. From 15 until $30 \mathrm{DAH}$, larvae were fed Artemia franciscana nauplii enriched with Selco at a density of 4-12 nauplii per milliliter. From 25 to $30 \mathrm{DAH}$, laboratory-grown Artemia were also added to the tanks. Samples of 30 larvae per tank were taken at hatching, and at

\section{Experimento 1: Efecto del tratamiento de choque frío sobre la división celular temprana}

Se usaron desoves de 13 hembras: 7 en 2008 y 6 en 2009. Cada desove fue fertilizado con semen de 3 a 4 machos. Se dividieron los huevos fertilizados de cada hembra en 2 grupos: grupo control (2 réplicas) y grupo sometido a choque frío (3 réplicas). Después del tratamiento de choque frío, aproximadamente 50 huevos de este grupo y 50 huevos del grupo control fueron depositados en microplacas de 12 pozos (4 huevos por pozo) con agua de mar estéril. Se determinó la división celular normal o anormal bajo un microscopio óptico de disección. Como la cabrilla arenera es una especie de desarrollo rápido, se observaron algunos desoves tan pronto como la fase de 4 células, mientras que otros no se observaron hasta la fase de 32 células, pero nunca después. Todos los embriones que no mostraron una división normal (ver Fig. 1a) fueron considerados anormales (Fig. 1b). Los embriones en la fase de 32 células fueron considerados normales o abnormales con base en la organización estructural de los blastómeros (Fig. 1c, d). Después de esta evaluación, se colocaron las microplacas de 12 pozos en una incubadora de temperatura controlada $\left(25^{\circ} \mathrm{C}\right)$. Después de la eclosión, se registró el número de embriones muertos y de larvas vitelinas vivas y muertas. Las larvas vitelinas que estaban dobladas o ligeramente opacas se registraron como muertas (Fig. 1e, f).

\section{Experimento 2: Relación entre la división celular anormal y el éxito de eclosión}

El procedimiento descrito arriba se repitió en 2009. En esta ocasión, para determinar si había una relación entre las tasas de eclosión y la división celular anormal, se separaron los embriones en 4 grupos: embriones del grupo control con división normal (1) y anormal (2), y embriones del grupo sometido a choque frío con división normal (3) y anormal (4). Se colocaron por separado en microplacas de 12 pozos y se incubaron como se describe arriba.

\section{Experimento 3: Efecto de la triploidía sobre la supervivencia durante el periodo larvario}

El porcentaje de triploidía se examinó en diferentes momentos durante el periodo larvario. Ya que los desoves por inducción hormonal de la cabrilla arenera producen pocos huevos, fue imposible usar réplicas. Por esta razón, el experimento se realizó con 3 desoves individuales. Se usaron de 4 a 5 machos para fertilizar los huevos de cada hembra. Se aplicó choque frío como se describió anteriormente. Se seleccionaron los desoves con porcentajes de triploidía de $\sim 80 \%$ con el fin de obtener larvas de ambas ploidías (triploides y diploides sometidas a choque frío) para seguir los porcentajes de ploidías durante el cultivo larvario. Los huevos fueron transferidos inmediatamente para su incubación $\left(\right.$ a $25^{\circ} \mathrm{C}$ y 

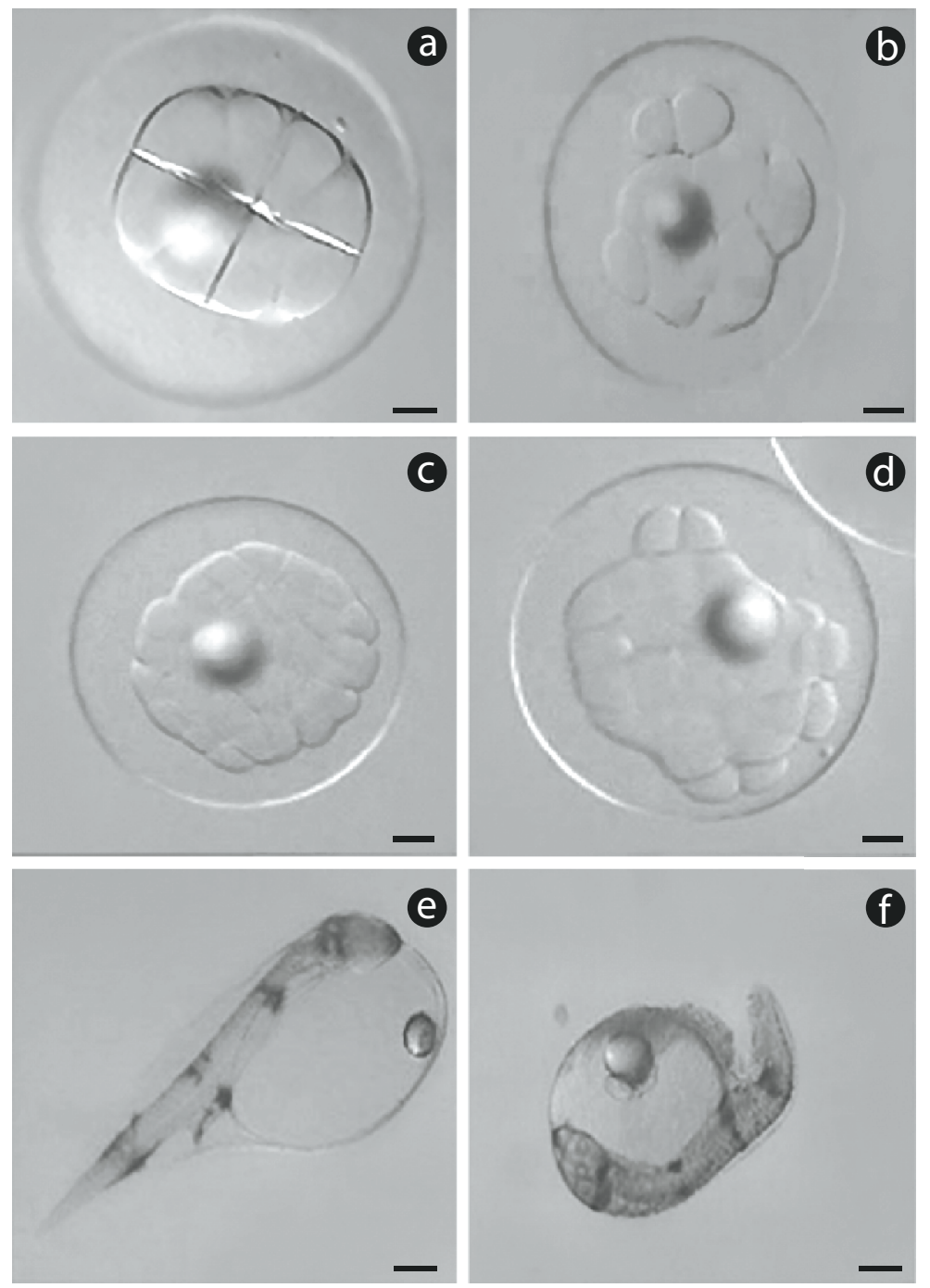

Figure 1. Digital photographs of representative spotted sand bass (Paralabrax maculatofasciatus): (a) normal cleavage and (b) abnormal cleavage in embryos at the 8-cell stage, (c) normal cleavage and (d) abnormal cleavage in embryos at the 32-cell stage, (e) normal hatched larvae, and (f) dead larvae. Scale bar $=90 \mu \mathrm{m}$.

Figura 1. Fotografías digitales representativas de la cabrilla arenera (Paralabrax maculatofasciatus): (a) división celular normal y (b) división celular anormal en embriones en la fase de 8 células, (c) división celular normal y (d) división celular anormal en embriones en la fase de 32 células, (e) larvas eclosionadas normales y (f) larvas muertas. Barra de escala $=90 \mu \mathrm{m}$.

5,15 , and $30 \mathrm{DAH}$. They were kept at $-80^{\circ} \mathrm{C}$ until the ploidy analysis was performed. The number of live larvae at day 30 (NL30) in the cold shock treatment and control groups were counted.

The number of triploid larvae at day 30 (T30) and the number of cold-shocked diploids at day 30 (CSD30) were evaluated using the following formulae:

$$
\begin{gathered}
\mathrm{T} 30=\mathrm{NL} 30 \times(\% \text { triploids on day } 30) \\
\text { CSD30 }=\text { NL30 }-\mathrm{T} 30
\end{gathered}
$$

The percentage of triploids to survive (ST) and the percentage of cold-shocked diploids to survive (SCSD) to day 30 were calculated as follows: salinidad de 35) a 2 tanques cónicos de $120 \mathrm{~L}$ de capacidad con circulación de agua. Veinticuatro horas después de la eclosión, se estimó el número de larvas vitelinas mediante métodos volumétricos. La densidad larvaria se estableció usando el número de larvas que sobrevivieron el tratamiento de choque frío. Las larvas del grupo control y del grupo sometido a choque frío fueron transferidas a 2 tanques separados de $100 \mathrm{~L}$ de capacidad. Se usó un fotoperiodo de 13:11 (luz:oscuridad). La temperatura y el oxígeno fueron medidos diariamente con un oxímetro $( \pm 0.1)$ (YSI modelo 58, Yellow Springs Instrument Co., Inc., Ohio). La salinidad se midió con un refractómetro (Aquafauna, Tokio).

El plan de alimentación fue el siguiente: de 1 a 18 días después de la eclosión (DDE) las larvas se alimentaron con 


$$
\begin{aligned}
\mathrm{ST} & =[(\mathrm{NL} 30 \times \% \text { triploids on day } 30) / \mathrm{IT}] \times 100 \\
\mathrm{SCSD} & =[(\mathrm{NL} 30-\text { no. triploids on day } 30) / \mathrm{ICSD}] \times 100
\end{aligned}
$$

where IT is the initial number of triploid larvae and ICSD is the initial number of cold-shocked diploid larvae.

Survival at hatching was calculated as the number of hatched larvae relative to the number of initial eggs and expressed as a percentage. The number of larvae used for ploidy determination was added to the total number of hatched larvae. The proportion of live yolk-sac larvae was calculated as the number of live yolk-sac larvae per hatched larvae. Ploidy was determined using flow cytometry (Partec Ploidy Analyser, Münster, Germany) as described by Alcántar-Vázquez et al. (2008). Triploidy was analyzed on a pool of 30 larvae, except on days 15 and 30 after hatching during the larval culture, when a muscle sample was taken from each larva and analyzed separately.

\section{Statistical analysis}

All percentage data were arcsine transformed prior to statistical analysis (Sokal and Rohlf 1998). The normality of the data was verified using the Kolmogorov-Smirnov test, while the homogeneity of variance was examined using the Levine test. For experiment 2, a general linear model that included year and treatment as fixed factors and the percentage of triploidy per spawn as a covariate was used $(\mathrm{Y}=$ arcsine of \%triploid + year + treatment + year*treatment $+\mathrm{e})$. When normal embryos were separated from abnormal embryos in the control and cold-shocked groups, we applied the same model, using treatment (control and cold-shocked eggs) and cellular division (normal or abnormal) as fixed factors. For cold-shocked eggs, the percentage of triploidy was used as a continuous predictor to assess its effects on cell cleavage, hatching success, and live yolk-sac larvae. Pearson's correlation coefficient was used to determine if there was a significant association between abnormal cleavage and survival at hatching or in the proportion of live yolk-sac larvae in the control and treated groups. In experiment 3, a one-way analysis of variance was used to identify differences in the percentage of triploidy during the larval period. A Tukey test was used when a significant difference was detected. The established level of significance for all analyses was $P<0.05$.

\section{RESULTS}

\section{Effect of triploidy on cell cleavage}

A significant negative Pearson's correlation coefficient was observed between arcsine-transformed percentages of abnormal cleavage and hatching $(r=-0.63 ; P<0.05)$ and the proportion of live yolk-sac larvae $(r=-0.58 ; P<0.05)$. The proportion of abnormally cleaved embryos was significantly higher $(P<0.05)$ in the cold-shocked group during rotíferos (Brachionus plicatilis) tipo $\mathrm{S}$ enriquecidos con Selco (Artemia System, Gante, Bélgica) a una densidad de 4-15 rotíferos por mililitro. De 15 a 30 DDE, se ofrecieron nauplios de Artemia franciscana enriquecidos con Selco a una densidad de 4-12 nauplios por mililitro. De 25 a 30 DDE, también se ofrecieron ejemplares de Artemia cultivados en el laboratorio. Se tomaron muestras de 30 larvas al momento de la eclosión y 5, 15 y 30 DDE, y se mantuvieron a $-80{ }^{\circ} \mathrm{C}$ hasta realizar el análisis de ploidía. Se contó el número de larvas vivas al día 30 (NL30) del grupo sometido a choque frío y del grupo control.

El número de larvas triploides al día 30 (T30) y el número de larvas diploides sometidas a choque frío al día 30 (CSD30) fueron evaluados con las siguientes fórmulas:

$$
\begin{gathered}
\mathrm{T} 30=\mathrm{NL} 30 \times(\% \text { triploides al día } 30) \\
\text { CSD30 }=\text { NL30 }-\mathrm{T} 30
\end{gathered}
$$

El porcentaje de triploides que sobrevivieron (ST) y el porcentaje de diploides sometidos a choque frío que sobrevivieron (SCSD) hasta el día 30 fueron calculados como sigue:

$$
\begin{aligned}
\mathrm{ST} & =[(\mathrm{NL} 30 \times \% \text { triploides al día } 30) / \mathrm{IT}] \times 100 \\
\mathrm{SCSD} & =[(\mathrm{NL} 30-\text { no. triploides al día } 30) / \mathrm{ICSD}] \times 100
\end{aligned}
$$

donde IT es el número inicial de larvas triploides e ICSD es el número inicial de larvas diploides sometidas a choque frío.

La supervivencia (expresada en porcentaje) al momento de la eclosión fue calculada como el número de larvas eclosionadas en relación al número inicial de huevos. El número de larvas usadas para determinar la ploidía se adicionó al número total de larvas eclosionadas. Se calculó la proporción de larvas vitelinas como el número de larvas vitelinas por larvas eclosionadas. La ploidía se determinó mediante citometría de flujo (Partec Ploidy Analyser, Münster, Alemania) según lo descrito por Alcántar-Vázquez et al. (2008). La triploidía se analizó a partir de un conjunto de 30 larvas, excepto los días 15 y 30 después de la eclosión, cuando se tomó una muestra de músculo de cada larva y se analizó por separado.

\section{Análisis estadístico}

Todos los porcentajes fueron sometidos a una transformación arcoseno antes del análisis estadístico (Sokal y Rohlf 1998). Se verificó la normalidad de los datos con la prueba de Kolmogorov-Smirnov y se evaluó la homogeneidad de la varianza con la prueba de Levine. Para el experimento 2, se usó un modelo lineal que incluyó el año y tratamiento como factores fijos y el porcentaje de triplodía por desove como una covariable $(\mathrm{Y}=$ arcoseno de $\%$ triploides + año + tratamiento + año*tratamiento $+\mathrm{e})$. Cuando se separaron los embriones normales y anormales del grupo control y el grupo sometido a choque frío, se usó el mismo modelo, con tratamiento (control y huevos sometidos a choque frío) y división 
both experimental years, while the hatching percentage and the proportion of live yolk-sac larvae were significantly lower $(P<0.05)$. The percentage of triploidy was significantly higher during the first year (experiment 1 ) than during the second year (experiment 2) (Table 1). The arcsinetransformed percentage of triploidy was not a significant covariate $(P=0.83)$ for survival at hatching, the proportion of abnormal cleavage, or the proportion of live yolk-sac larvae. There was no interaction between treatment and experimental year for any of these variables.

\section{Link between abnormal cleavage and hatching success}

When the normally cleaved embryos of the control and cold-shocked groups were incubated separately from the abnormally cleaved embryos, significant differences $(P<0.05)$ were observed in the hatching percentage and the percentage of live yolk-sac larvae (Table 2). Hatching percentages $(P=0.017)$ were significantly different due to the significantly lower hatching percentage for abnormally cleaved embryos from the cold shock treatment group $(P<0.05)$ compared to normally cleaved embryos. No significant difference was observed between normal and abnormal embryos in the control group. A significant higher number of live yolk-sac larvae $(P<0.05)$ were observed in normally cleaved embryos from the control group, while a significantly lower number was observed in the abnormally cleaved embryos from the cold shock treatment group (Table 2).

\section{Percentages of triploidy during the larval period}

A significant decrease in triploidy percentages $(P<0.05)$ was observed throughout the larval period in the 3 individual

Table 1. Percentages of abnormal cleavage (AC), hatching $(\mathrm{H})$, liveyolk larvae (LL), and triploidy (T) (mean \pm standard error) for the control (C) and cold-shocked (CS) spotted sand bass (Paralabrax maculatofasciatus) eggs in experiments $1(n=7)$ and $2(n=6)$.

Tabla 1. Porcentajes de división celular anormal (AC), eclosión $(\mathrm{H})$, larvas vivas (LL) y triploidía (T) (promedio \pm error estándar) para los huevos de la cabrilla arenera (Paralabrax maculatofasciatus) del grupo control (C) y del grupo sometido a choque frío (CS) en los experimentos $1(n=7)$ y $2(n=6)$.

\begin{tabular}{lccccc}
\hline & \multicolumn{2}{c}{ Experiment 1 } & & \multicolumn{2}{c}{ Experiment 2 } \\
\cline { 2 - 3 } \cline { 5 - 6 } & $\mathrm{C}$ & $\mathrm{CS}$ & & $\mathrm{C}$ & $\mathrm{CS}$ \\
\hline $\mathrm{AC}^{*}$ & $24.6 \pm 1.0^{\mathrm{c}}$ & $45.7 \pm 2.1^{\mathrm{a}}$ & & $16.4 \pm 1.6^{\mathrm{c}}$ & $34.2 \pm 4.2^{\mathrm{b}}$ \\
$\mathrm{H}$ & $76.8 \pm 5.8^{\mathrm{a}}$ & $37.7 \pm 2.5^{\mathrm{c}}$ & & $75.1 \pm 3.8^{\mathrm{a}}$ & $57.5 \pm 7.8^{\mathrm{b}}$ \\
$\mathrm{LL}$ & $87.5 \pm 3.5^{\mathrm{a}}$ & $70.4 \pm 6.6^{\mathrm{b}}$ & & $92.2 \pm 1.9^{\mathrm{a}}$ & $67.6 \pm 6.5^{\mathrm{b}}$ \\
$\mathrm{T}$ & & $78.0 \pm 6.3^{\mathrm{a}}$ & & & $50.0 \pm 5.3^{\mathrm{b}}$ \\
\hline
\end{tabular}

* Means for untransformed data. Superscript letters indicate significant differences in each row $(P<0.05)$. celular (normal o anormal) como factores fijos. Para los huevos sometidos a choque frío, se usó el porcentaje de triploidía como un predictor continuo para evaluar su efecto sobre la división celular, el éxito de eclosión y las larvas vitelinas vivas. Se usó el coeficiente de correlación de Pearson para determinar si existía una relación significativa entre la división anormal y la supervivencia a la eclosión o entre la proporción de larvas vitelinas vivas en el grupo control y el grupo sometido a choque frío. En el experimento 3, se usó un análisis de varianza de una vía para identificar las diferencias en el porcentaje de triploidía durante el periodo larvario y, cuando se detectó una diferencia significativa, se usó la prueba de Tukey. El nivel de significancia establecido para todos los análisis fue $P<0.05$.

\section{Resultados}

\section{Efecto de la triploidía sobre la división celular}

Se observó un coeficiente de correlación de Pearson significativamente negativo entre los porcentajes transformados de la división celular anormal y eclosión $(r=-0.63 ; P<0.05)$ y la proporción de larvas vitelinas vivas $(r=-0.58 ; P<0.05)$. La proporción de embriones con división anormal fue significativamente mayor $(P<0.05)$ en el grupo sometido a choque frío en ambos años experimentales, mientras que el porcentaje de eclosión y la proporción de larvas vitelinas vivas fue significativamente menor $(P<0.05)$. El porcentaje de triploidía fue significativamente mayor durante el primer año (experimento 1) que durante el segundo (experimento 2) (Tabla 1). El porcentaje transformado de triploidía no fue una covariable significativa $(P=0.83)$ para la supervivencia a la eclosión, la proporción de división anormal o la proporción de larvas vitelinas vivas. Ninguna de estas variables mostró alguna interacción entre tratamiento y año.

\section{Relación entre la división celular anormal y el éxito de eclosión}

Cuando los embriones con divisiones normales y anormales del grupo control y el grupo sometido a choque frío fueron incubados por separado, se observaron diferencias significativas $(P<0.05)$ en el porcentaje de eclosión y el porcentaje de larvas vitelinas vivas (Tabla 2). Los porcentajes de eclosión fueron significativamente diferentes $(P=0.017)$ debido a que el porcentaje de eclosión fue significativamente menor $(P<0.05)$ para los embriones anormales del grupo sometido a choque frío en comparación con los embriones normales. No se observó una diferencia significativa entre los embriones normales y anormales del grupo control. El número de larvas vitelinas vivas fue significativamente más alto $(P<0.05)$ en los embriones normales del grupo control y significativamente más bajo en los embriones anormales del grupo sometido a choque frío (Tabla 2). 
Table 2. Hatching percentage $(\mathrm{H})$ and percentage of live-yolk larvae (LL) (mean \pm standard error) obtained from abnormally and normally cleaved embryos of spotted sand bass.

Tabla 2. Porcentajes de eclosión (H) y de larvas vivas (LL) (promedio \pm error estándar) obtenidos para embriones de la cabrilla arenera con divisiones celulares normales y anormales.

\begin{tabular}{lcc}
\hline & $\mathrm{H}^{*}$ & $\mathrm{LL}$ \\
\hline Control group & & \\
$\quad$ Normal & $98.8 \pm 0.8^{\mathrm{a}}$ & $93.3 \pm 1.5^{\mathrm{a}}$ \\
$\quad$ Abnormal & $95.3 \pm 3.0^{\mathrm{a}}$ & $78.5 \pm 6.2^{\mathrm{b}}$ \\
Cold-shocked group & & \\
$\quad$ Normal & $83.9 \pm 5.1^{\mathrm{b}}$ & $73.5 \pm 5.5^{\mathrm{b}}$ \\
Abnormal & $43.9 \pm 12.3^{\mathrm{c}}$ & $54.5 \pm 10.0^{\mathrm{c}}$ \\
\hline
\end{tabular}

* Means for untransformed data. Superscript letters indicate significant differences in each column $(P<0.05)$.

spawns (Table 3). The number of pre-juveniles on day 30 (NL30) was higher in the control than in the cold-shocked group (Table 4). In the cold-shocked group, the percentage of diploids to survive to day 30 (SCSD) was higher than that for triploids, but close to that observed for the control group for the 3 spawns. On day 30 , the number of diploid cold-shocked pre-juveniles was always higher than the number of triploids for the 3 spawns (Table 4).

\section{DisCUSSION}

In this study, higher mortality related to abnormal cleavage in cold-shocked spotted sand bass embryos was observed. Moreover, decreasing percentages of triploids were recorded during larval rearing.

Abnormal cell cleavages were observed in the control and cold-shocked groups; however, while the rate of abnormal cleavage was $25 \%$ in the control group, hatching success exceeded $90 \%$. These results are consistent with those of Vallin and Nissling (1998), who argue that deviations in undifferentiated early-stage cod cells (4 to 32 cells) allow further development to proceed normally until hatching. Rideout et al. (2004) note that viability varies in abnormally cleaved embryos and depends on the type of blastomeric abnormality. Moreover, proteins and repair mechanisms are constantly working to reduce abnormal blastomeres and embryo mortality, acting as checkpoints during cell division (Gerald 2005). However, when normally and abnormally cleaved embryos in the control and treated groups were separated, a significant negative correlation was observed between abnormally cleaved embryos and hatching only in the cold-shocked eggs. Hence, a high proportion of abnormally treated eggs did not hatch. Self-repair mechanisms are probably disrupted during the cold shock treatment due to changes in intracellular proteins. Felip et al. (1997) and Piferrer et al. (2003) suggest that the increase in abnormal
Table 3. Percentage* of triploidy at hatching (TH) and at 5 (T5), 15 (T15), and 30 (T30) days after hatching. Data from individual spotted sand bass spawns $\left(\mathrm{S}_{1}, \mathrm{~S}_{2}, \mathrm{~S}_{3}\right)$.

Tabla 3. Porcentaje* de triploidía a la eclosión (TH) y a 5 (T5), 15 (T15) y 30 (T30) días después de la eclosión. Datos de desoves individuales $\left(\mathrm{S}_{1}, \mathrm{~S}_{2}, \mathrm{~S}_{3}\right)$ de la cabrilla arenera.

\begin{tabular}{llll}
\hline & $\mathrm{S}_{1}$ & $\mathrm{~S}_{2}$ & $\mathrm{~S}_{3}$ \\
\hline Initial larval density (larvae/L) & 29 & 70 & 35 \\
TH & $62^{\mathrm{a}}$ & $54^{\mathrm{a}}$ & $77^{\mathrm{a}}$ \\
T5 & $45^{\mathrm{b}}$ & $41^{\mathrm{b}}$ & $55^{\mathrm{b}}$ \\
T15 & $26^{\mathrm{c}}$ & $19^{\mathrm{c}}$ & $43^{\mathrm{c}}$ \\
T30 & $14^{\mathrm{d}}$ & $10^{\mathrm{d}}$ & $28^{\mathrm{d}}$
\end{tabular}

* Means of untransformed data. Superscript letters indicate significant differences in each column $(P<0.05)$.

\section{Porcentajes de triploidía durante el periodo larvario}

Se observó una disminución significativa $(P<0.05)$ de los porcentajes de triploidía durante el periodo larvario en los 3 desoves individuales (Tabla 3). El número de prejuveniles al día 30 (NL30) fue mayor en el grupo control que en el grupo sometido a choque frío (Tabla 4). En el grupo sometido a choque frío, el porcentaje de diploides que sobrevivieron al día 30 (SCSD) fue mayor que el de triploides, pero cerca a lo observado para el grupo control en los 3 desoves. Al día 30, en los 3 desoves, el número de prejuveniles diploides sometidos a choque frío siempre fue mayor que el número de triploides (Tabla 4).

\section{DisCuSIÓN}

En el presente estudio se observó una mayor mortalidad relacionada con la división celular anormal en los embriones de la cabrilla arenera sometidos a choque frío. Además, se registró una disminución de la cantidad de triploides durante el periodo larvario.

Se observó división celular anormal tanto en el grupo control como en el grupo sometido a choque frío; sin embargo, mientras que la tasa de división anormal fue de $25 \%$ en el grupo control, el éxito de eclosión fue $>90 \%$. Estos resultados coinciden con los de Vallin y Nissling (1998), quienes argumentan que divergencias en las células tempranas no diferenciadas de bacalao ( 4 a 32 células) permiten que el desarrollo proceda normalmente hasta la eclosión. Rideout et al. (2004) indicaron que la viabilidad varía en embriones con división anormal y depende del tipo de anormalidad blastomérica. Además, las proteínas y los mecanismos de reparación están constantemente trabajando para reducir los blastómeros anormales y la mortalidad embrionaria, actuando como puntos de control durante la división celular (Gerald 2005). Sin embargo, cuando se separaron los 
Table 4. Initial number of larvae (IL), initial number of triploid larvae (IT), initial number of cold-shocked diploid larvae (ICSD), number of pre-juveniles at day 30 (NL30), survival percentage at day 30 (S), triploid survival percentage at day 30 (ST), and cold-shocked diploid survival percentage at day 30 (SCSD). Data from individual spotted sand bass (Paralabrax maculatofasciatus) spawns.

Tabla 4. Número inicial de larvas (IL), número inicial de larvas triploides (IT), número inicial de larvas diploides sometidas a choque frío (ICSD), número de prejuveniles al día 30 (NL30), porcentaje de supervivencia al día 30 (S), porcentaje de supervivencia de larvas triploides al día 30 (ST) y porcentaje de supervivencia de larvas diploides sometidas a choque frío al día 30 (SCSD). Datos de desoves individuales de la cabrilla arenera (Paralabrax maculatofasciatus).

\begin{tabular}{|c|c|c|c|c|c|c|}
\hline & \multicolumn{2}{|c|}{ Spawn 1} & \multicolumn{2}{|c|}{ Spawn 2} & \multicolumn{2}{|c|}{ Spawn 3} \\
\hline IL & 2900 & 2900 & 7000 & 7000 & 3500 & 3500 \\
\hline $\mathrm{IT}^{\mathrm{a}}$ & 1798 & - & 3780 & - & 2695 & - \\
\hline $\mathrm{ICSD}^{\mathrm{b}}$ & 1102 & - & 3220 & - & 805 & - \\
\hline NL30 & 135 & 342 & 199 & 686 & 111 & 431 \\
\hline $\mathrm{ST}^{\mathrm{d}}$ & 1.1 & - & 0.5 & - & 1.2 & - \\
\hline $\mathrm{SCSD}^{\mathrm{e}}$ & 10.5 & - & 5.5 & - & 9.9 & - \\
\hline
\end{tabular}

${ }^{\mathrm{a}} \mathrm{IT}=(\mathrm{IL} \times \%$ triploids at hatching $) ;{ }^{\mathrm{b}} \mathrm{ICSD}=\mathrm{IL}-\mathrm{IT} ;{ }^{\mathrm{c}} \mathrm{S}=(\mathrm{NL} 30 / \mathrm{IL}) \times 100 ;{ }^{\mathrm{d}} \mathrm{ST}=[(\mathrm{NL} 30 \times \%$ triploids on day 30$) / \mathrm{IT}] \times 100$;

${ }^{\mathrm{e}} \mathrm{SCSD}=[(\mathrm{NL} 30-$ number of triploids on day 30$) / \mathrm{ICSD}] \times 100$.

cell cleavage observed following cold shock treatment may be the result of aneuploidy. The addition of a third set of chromosomes may interfere during the anaphase. These additional chromosomes may affect the alignment of the mitotic spindle in the early stages of mitosis, changing the dynamics of the microtubules during cell division and, consequently, modifying the distribution of genetic material and cytoplasmic volume between daughter cells (Gerald 2005, Voronina and Wessel 2006). On the other hand, abnormal cleavage may be due to the cold shock intensity. Intracellular proteins involved in the formation of microtubules may be negatively impacted, resulting in aneuploidy or a disruption of the action and distribution of specific proteins in each half of the dividing cells (Downing and Allen 1987, Voronina and Wessel 2006).

In Atlantic cod, which inhabit cold waters, Sultana (2005) did not find any differences in the percentage of embryos showing abnormal cleavage between cold-shock and control groups. In fact, the percentage of abnormal cleavage in embryos was very low, as was the hatching percentage for both groups. The temperature differential between maintenance temperature and cold shock temperature seems to be more important than the shock temperature itself (Diaz et al. 1993). The difference was only $5^{\circ} \mathrm{C}$ in the Atlantic cod experiment; in our experiment it was $14^{\circ} \mathrm{C}$. This difference may explain the high proportion of abnormal cleavage in our study.

Larval rearing in our study resulted in poor survival of triploid spotted sand bass larvae compared with the control and cold-shocked diploid groups. Survival in the control diploid group was similar to that reported by Álvarez-González et al. (2000) in a previous study with the same species in our laboratory. Higher mortality of triploid larvae compared with embriones con divisiones normales y anormales en nuestros 2 grupos experimentales, sólo se observó una correlación negativa significativa entre los embriones anormales y la eclosión en los huevos sometidos a choque frío; por ende, una proporción alta de huevos anormales no eclosionaron. Es probable que se interrumpan los mecanismos de autoreparación durante el tratamiento de choque frío debido a cambios en las proteínas intracelulares. Felip et al. (1997) y Piferrer et al. (2003) sugieren que el incremento de división celular anormal que se observa después de un tratamiento de choque frío puede ser resultado de aneuploidía. La adición de un tercer juego de cromosomas podría interferir durante la anafase. Estos cromosomas adicionales podrían afectar la alineación del huso mitótico en las etapas tempranas de la mitosis, y cambiar la dinámica de los microtúbulos durante la división celular $\mathrm{y}$, consecuentemente, modificar la distribución del material genético y el volumen citoplasmático entre las células hijas (Gerald 2005, Voronina y Wessel 2006). Por otro lado, la división anormal puede ser resultado de la intensidad del choque frío. Las proteínas intracelularles involucradas en la formación de microtúbulos pueden ser afectados negativamente, lo que provocaría aneuploidía o una interrupción de la acción y distribución de proteínas específicas en cada mitad de las células en división (Downing y Allen 1987, Voronina y Wessel 2006).

En el bacalao del Atlántico, que vive en aguas frías, Sultana (2005) no observó diferencias en el porcentaje de embriones con división anormal entre el grupo sometido a choque frío y el grupo control. De hecho, el porcentaje de embriones con división anormal así como el porcentaje de eclosión fueron muy bajos para ambos grupos. La diferencia entre la temperatura del choque frío y la temperatura de 
control diploids has been reported by Solar et al. (1984). They suggest that this gradual decrease in survival may be the result of a degree of inbreeding caused by the retention of the second polar body.

However, the negative effect of the intensity of the cold shock cannot be overlooked. Individuals not responding to thermal shock treatment when triploidy induction is not $100 \%$ can serve as controls to determine the effect of shock intensity on the survival and growth rates during the larval period (Piferrer et al. 2009). Maxime (2008) suggests that it seems unlikely that temperatures used during the triploidy induction treatment are intense enough to disrupt development beyond early embryogenesis. The percentages of coldshocked diploids in the 3 spawns were close to that observed in the control group, suggesting that cold shock intensity was not responsible for the low survival of triploids.

We have no conclusive evidence regarding the differential mortality between triploid and cold-shocked diploid larvae. Many differences between triploid and diploid fish have been reported that may affect larval performance and survival. Abnormal behavior, including unusual swimming and feeding behavior (Solar et al. 1984), has been reported for triploid larvae of some species (Piferrer et al. 2009). A less aggressive behavior has been reported for triploid juveniles (Galbreath et al. 1994). Lower jaw (Lijalad and Powell 2009), gas bladder, and skeletal deformities (Tiwary and Ray 2004) have also been observed in triploid fish. The reduction of the cell surface area related to the elevation of ploidy status and its potential relation to several negative biological and physiological characteristics, including the reduction in the cell number in some organs (Swarup 1959), circulating blood cell number, oxygen carrying capacity (Saddler et al. 2000), metabolic pathways (Hyndman et al. 2003, Atkins and Benfey 2008), and stress response (Beyea et al. 2005) have also been proposed.

In conclusion, this study showed that mortality in embryos of cold-shocked treated spotted sand bass can be attributed to abnormal cell cleavage resulting from the $8{ }^{\circ} \mathrm{C}$ cold shock, leading to lower hatching than that observed in abnormally cleaved embryos from the control group. Also, a differential survival rate was observed between triploid and cold-shocked diploids, translating into low triploidy percentages at the end of the larval period. This represents a serious impediment for the production of triploid spotted sand bass. A possible solution might be to conduct larval culture exclusively with cold-shock treated spawns that have resulted in $100 \%$ triploidity. Important research remains to be done to ascertain the viability of triploid spotted sand bass culture. A logical next step would be to focus on investigating the sexual maturity of triploid spotted sand bass.

\section{ACKNOWLEDGMENTS}

This work was funded by the Department of Research and Postgraduate Studies of the National Polytechnical Institute mantenimiento parece ser más importante que la propia temperatura del choque (Diaz et al. 1993). La diferencia fue de sólo $5{ }^{\circ} \mathrm{C}$ en el experimento con el bacalao del Atlántico y de $14^{\circ} \mathrm{C}$ en nuestro experimento. Esta diferencia podría explicar la alta proporción de división anormal en nuestro estudio.

En el presente estudio, durante el cultivo de larvas de la cabrilla arenera, el porcentaje de supervivencia de las larvas triploides fue menor que el de las diploides sometidas a choque frío y del grupo control. La supervivencia de las larvas diploides del grupo control fue similar a la obtenida por Álvarez-González et al. (2000) en un estudio previo con la misma especie en nuestro laboratorio. Una mayor mortalidad de larvas triploides que de diploides control ha sido documentada por Solar et al. (1984), quienes sugieren que esta disminución gradual en la supervivencia puede ser resultado de un grado de endogamia causada por la retención del segundo cuerpo polar.

No obstante, no se puede ignorar la intensidad del choque frío. Los individuos que no responden a choques térmicos cuando la inducción a la triploidía no es del $100 \%$ pueden servir como controles para determinar el efecto de la intensidad del choque sobre la supervivencia y las tasas de crecimiento durante el periodo larvario (Piferrer et al. 2009). Maxime (2008) sugiere que es poco probable que las temperaturas usadas durante el tratamiento de inducción a la triploidía sean lo suficientemente intensas para interrumpir el desarrollo después de la embriogénesis temprana. Los porcentajes de diploides sometidos a choque frío en los 3 desoves fueron similares a los obtenidos para el grupo control, lo que sugiere que la intensidad del choque frío no fue responsable de la baja supervivencia de las larvas triploides.

No tenemos evidencia concluyente de la mortalidad diferencial entre las larvas triploides y las larvas diploides sometidas a choque frío. Se han documentado varias diferencias entre peces triploides y diploides que pueden afectar el desarrollo y la supervivencia de larvas. Se han registrado comportamientos anormales, incluyendo comportamiento natatorio y alimentario inusual (Solar et al. 1984), para larvas triploides de algunas especies (Piferrer et al. 2009). Se ha registrado un comportamiento menos agresivo para juveniles triploides (Galbreath et al. 1994), y en peces triploides se han observado deformidades de la mandíbula inferior (Lijalad y Powell 2009), de la vejiga natatoria y esqueléticas (Tiwary y Ray 2004). También se ha propuesto la disminución del área superficial de una célula asociada a la elevación del estatus de ploidía y su potencial relación con varias características biológicas y fisiológicas negativas, entre ellas la disminución del número de células en algunos órganos (Swarup 1959), el número de células en la sangre circulante, la capacidad de transportar oxígeno (Saddler et al. 2000), rutas metabólicas (Hyndman et al. 2003, Atkins y Benfey 2008) y la respuesta al estrés (Beyea et al. 2005).

En conclusión, la mortalidad de embriones de la cabrilla arenera sometidos a choque frío puede atribuirse a la división celular anormal provocada por el choque frío $\left(8^{\circ} \mathrm{C}\right)$, lo que 
(SIP-IPN grants 20070038, 20082246, 20090537). SD and RP are COFAA-IPN and EDI-IPN fellows.

\section{REFERENCES}

Alcántar-Vázquez JP, Dumas S, Puente-Carreón E, Pliego-Cortés HS, Peña R. 2008. Induction of triploidy in spotted sand bass (Paralabrax maculatofasciatus Steindachner 1868) by cold shock. Aquacult. Res. 39: 59-63.

Álvarez-González CA, Civera-Cerecedo R, Ortiz-Galindo JL, Dumas S, Moreno-Legorreta M, Grayeb-del Alamo T. 2001. Effect of dietary protein level on growth and body composition of juvenile spotted sand bass, Paralabrax maculatofasciatus, fed practical diets. Aquaculture 194: 151-159.

Álvarez-González CA, Ortiz-Galindo JL, Dumas S, Martínez-Díaz S, Hernández Ceballos DE, Grayeb-del Alamo T, MorenoLegorreta M, Peña-Martínez R, Civera-Cerecedo R. 2000. Effect of stocking density on the growth and survival of spotted sand bass Paralabrax maculatofasciatus larvae in a closed recirculating system. J. World Aquacult. Soc. 32: 130-137.

Atkins ME, Benfey TJ. 2008. Effect of acclimation temperature on routine metabolic rate in triploid salmonids. Comp. Biochem. Physiol. A 149: 157-161.

Avery TS, Brown AJ. 2005. Investigating the relationship among abnormal patterns of cell cleavage, egg mortality and early larval condition in Limanda ferruginea. J. Fish Biol. 67: 890-892.

Beyea MM, Benfey TJ, Kieffe JD. 2005. Hematology and stress physiology of juvenile diploid and triploid shortnose sturgeon (Acipenser brevirostrum). Fish Physiol. Biochem. 31: 303-313

Diaz NF, Iturra P, Veloso A, Estay F, Colihueque N. 1993. Physiological factors affecting triploid production in rainbow trout, Oncorhynchus mykiss. Aquaculture 114: 33-40.

Downing SL, Allen Jr SK. 1987. Induced triploidy in the Pacific oyster Crassostrea gigas. Optimal treatments with cytochalasin B depend on temperature. Aquaculture 61: 1-15.

Dunham RA. 2004. Aquaculture and Fisheries Biotechnology: Genetic Approaches. CABI Publishing, Wallingford, UK.

Felip A, Piferrer F, Zanuy S, Carrillo M. 2001. Comparative growth performance of diploid and triploid European sea bass over the first four spawning seasons. J. Fish Biol. 58: 76-88.

Felip A, Zanuy S, Carrillo M, Martínez G, Ramos J, Piferrer F. 1997. Optimal conditions for the induction of triploidy in the sea bass (Dicentrarchus labrax L.). Aquaculture 152: 287-298.

Galbreath FP, St Jean W, Anderson V, Thorgaard GH. 1994. Freshwater performance of all-female diploid and triploid Atlantic salmon. Aquaculture 128: 41-49.

Gerald K. 2005. Cell and Molecular Biology: Concepts and Experiments. 4th ed. John Wiley and Sons, Hoboken, NJ, USA.

Grayeb del Alamo T. 2001. Efecto de la densidad en el crecimiento de la cabrilla arenera Paralabrax maculatofasciatus (Percoidei: Serranidae) cultivada en jaulas flotantes. MSc thesis, Centro Interdisciplinario de Ciencias Marinas, La Paz, Baja California Sur, México.

Hyndman CA, Kieffer JD, Benfey TJ. 2003. Physiology and survival of triploid brook trout following exhaustive exercise in warm water. Aquaculture 221:629-643.

Johnstone R. 1985. Induction of triploidy in Atlantic salmon by heat shock. Aquaculture 49: 133-139.

Kjørsvik E, Hoelhne-Reitan K, Reitan KI. 2003. Egg and larval quality criteria as predictive measures for juvenile production in turbot (Scophthalmus maximus L.). Aquaculture 227: 9-20. resultó en una menor eclosión que la observada en embriones con división anormal del grupo control. Asimismo, se registró una tasa de supervivencia diferencial entre las larvas triploides y las diploides sometidas a choque frío, lo que se tradujo en porcentajes bajos de triploides al final del periodo larvario. Esto representa un serio impedimento para la producción de larvas triploides de la cabrilla arenera. Una posible solución sería realizar el cultivo larvario exclusivamente con desoves sometidos a choque frío que han resultado en $100 \%$ de triploidía. Se necesita realizar más investigación para determinar la viabilidad de cultivar larvas triploides de la cabrilla arenera, y un próximo paso lógico sería estudiar su maduración sexual.

\section{AgRadecimientos}

Este trabajo fue financiado por la Secretaría de Investigación y Posgrado del Instituto Politécnico Nacional (SIP-IPN proyectos 20070038, 20082246 y 20090537). SD y RP son becarios de COFAA-IPN y EDI-IPN.

Traducido al español por Christine Harris.

Kjørsvik E, Mangor-Jensen A, Holmefjord I. 1990. Egg quality in fishes. Adv. Mar. Biol. 26: 71-113.

Lijalad M, Powell MD 2009. Effects of lower jaw deformity on swimming performance and recovery from exhaustive exercise in triploid and diploid Atlantic salmon Salmo salar L. Aquaculture 290: 145-154.

Maxime V. 2008. The physiology of triploid fish: Current knowledge and comparisons with diploid fish. Fish Fish. 9: 67-78.

Opstad I, Fjelldal PG, Karlsen Ø, Thorsen A, Hansen TJ, Taranger GL. 2013. The effect of triploidization of Atlantic cod (Gadus morhua L.) on survival, growth and deformities during early life stages. Aquaculture 388-391: 54-59.

Penney RW, Lush LP, Wade J, Brown AJ, Parrish CC, Burton MP. 2006. Comparative utility of egg blastomere morphology and lipid biochemistry for prediction of hatching success in Atlantic cod, Gadus morhua L. Aquacult. Res. 37: 272-283.

Peruzzi S, Kettunen A, Primicerio R, Kauric G. 2007. Thermal shock induction of triploidy in Atlantic cod (Gadus morhua L.). Aquacult. Res. 38: 926-932.

Piferrer F, Beaumont A, Falguiere JC, Flajshans M, Haffray P, Colombo L. 2009. Polyploid fish and shellfish: Production, biology and applications to aquaculture for performance improvement and genetic containment. Aquaculture 293: $125-156$.

Piferrer F, Cal RM, Álvarez-Blázquez B, Sánchez B, Martínez P. 2000. Induction of triploidy in the turbot (Scophthalmus maximus) I. Ploidy determination and the effects of cold shocks. Aquaculture 188: 79-90.

Piferrer F, Cal RM, Gómez C, Bouza C, Martínez P. 2003. Induction of triploidy in the turbot (Scophthalmus maximus). II. Effects of cold shock timing and induction of triploidy in a large volume of eggs. Aquaculture 200: 821-831.

Rideout RM, Trippel EA, Litvak MK. 2004. Predicting haddock embryo viability based on early cleavage patterns. Aquaculture 230: $215-228$. 
Saddler J, Wells RM, Pankhurst MP, Pankhurst NW. 2000. Blood oxygen transport, rheology and haematological responses to confinement stress in diploid and triploid Atlantic salmon, Salmo salar. Aquaculture 184: 349-361.

Sokal RR, Rohlf FJ. 1998. Biometry: The principles and practices of statistics in biological research. 3rd ed. WH Freeman and Company, New York.

Solar I, Donaldson EM, Hunter GA. 1984. Induction of triploidy in rainbow trout (Salmo gairdneri) by heat shock and investigation of early growth. Aquaculture 42: 57-67.

Sultana RM. 2005. Prediction of larval viability based on egg quality parameters and early cleavage patterns in the experiments of triploidy induction in Atlantic cod, Gadus morhua L. MSc thesis. University of Tromsø, Norway.

Swarup H. 1959. The oxygen consumption of diploid and triploid Gasterosteus aculeatus (L). J. Genet. 56: 156-160.

Tiwary BK, Ray AK. 2004. Alterations in air-sac and skeleton of triploid Heteropneustes fossilis J. Fish Biol. 64: 268-272.

Vallin L, Nissling A. 1998. Cell morphology as an indicator of viability of cod egg-results from an experimental study. Fish. Res. 38: 247-255.

Voronina E, Wessel GM. 2006. Activator of G-protein signaling in asymmetric cell divisions of the sea urchin embryo. Dev. Growth Differ. 48: 549-557.

Received September 2015, accepted April 2016. 